РОЛЬ СОЦІАЛЬНО-ПСИХОЛОГІЧНОЇ РЕАБІЛІТАЦІЇ

В ПІДВИЩЕННІ АДАПТАЦІЙНИХ МОЖЛИВОСТЕЙ ОСІБ, ЯКІ СТРАЖДАЮТЬ НА ПСИХІЧНІ РОЗЛАДИ

\title{
THE ROLE OF SOCIAL-PSYCHOLOGICAL REHABILITATION IN INCREASING THE ADAPTATION CAPABILITIES OF PERSONS SUFFERING OF MENTAL DISORDERS
}

УДК 364.62-786-787.522:616.89-052 DOI https://doi.org/10.32843/26635208.2021.23.38

\section{Сургова С.ю.}

к.пед.н.,

доцент кафедри соціальної роботи, управління і педагогіки

Чорноморський національний університет імені Петра Могили

\section{Файчук О.Л.}

к.пед.н.,

доцент кафредри соціальної роботи, управління і педагогіки

Чорноморський національний

університет імені Петра Могили

\section{Комарова Н.В.}

соціальний працівник з реабілітації душевнохворих

Реабілітаційний центр психічного здоров'я (Арада, Ізраїль) у статmі розглянуто питання ефрективності використання методу координованої інтервенції в роботі з особами, які страждають на психічні розлади, в умовах реабілітаційного центру. Проаналізовано досвід соціальної роботи з такою категорією в Ізраїлі. Виявлено ефрективність запропонованої методики вивчати складні або емоційно значущі проблеми осіб, які страждають на психічні розлади, в безпечних обставинах. Визначено мету, принципи, завдання, методи реабілітації осіб, які страждають на психічні розлади. З'ясовано, що успіх процесу реабілітації залежить не тільки від подальшої діяльності самих пацієнтів, але й від знань та умінь працівників центру реабілітації, їх кваліфрікації, а також бажання самих пацієнтів досягти прогресу в боротьбі зі своєю хворобою. Проведено діагностику стану психологічної реабілітації осіб, які страждають на психічні розлади, й виявлено есрективність методики координованої інтервенції як умови успішноїїх реабілітації. Упровадження методики координованої інтервенції в роботу центру реабілітації осіб, які страждають на психічні розлади, полягало в навчанні пацієнтів основам самоконтролю хвороби, заснованим на моделі стрес-уразливості, тобто впливу ліків, посиленні соціальної підтримки й залученні до трудової діяльності. Установлено, що роботі, яка ведеться соціальними працівниками з особами, які страждають на психічні розлади, в Ізраїлі немає аналогів в Україні, а в українському суспільстві робляться перші кроки в покращенні стану здоров'я зазначеної категорії, тому запозичення ізраїльського досвіду в такому напрямі досить актуальне.

Запропоновані в ході дослідження заходи дозволяють значно покращити стан здоров'я пацієнтів, а саме: зменшити тривожність, підвищити психологічний рівень соціальної адаптованості до умов соціуму, відчуття потрібності, бажання жити.

Ключові слова: реабілітаційний центр психічного здоров'я, соціальна робота, координована інтервенція, особи, які страждають на психічні розлади, соціально-психологічна терапія.

The article discusses the issues of the effectiveness of using the method of coordinated intervention during the work with persons suffering from mental disorders in a rehabilitation center. The experience of social work with this category in Israel is analyzed. The effectiveness of the proposed methodology to study complex or emotionally significant problems of persons suffering from mental disorders in safe circumstances was revealed. The goals, principles, objectives, methods of rehabilitation of persons suffering from mental disorders are determined. It is found that the success of the rehabilitation process depends not only on the further activities of the patients themselves, but also on the knowledge and skills of the employees of the rehabilitation center, their qualifications, as well as the desire of the patients themselves to achieve progress in the fight against their disease. The diagnostics of the state of psychological rehabilitation of persons suffering from mental disorders was carried out and the effectiveness of the method of coordinated intervention was revealed as a condition for their successful rehabilitation. The introduction of a coordinated intervention method in the work of a rehabilitation center for persons with mental disorders consisted in teaching patients the basics of self-control of the disease based on a stress vulnerability model, that is, exposure to drugs, strengthening social support and engaging in work. It was found that the work carried out by social workers with persons suffering from mental disorders in Israel has no analogues in Ukraine, and in the Ukrainian society the first steps are being taken to improve the health status of this category, therefore, borrowing the Israeli experience in this direction is very relevant. The measures proposed in the course of the study make it possible to significantly improve the health of patients, namely: to reduce anxiety, to increase the psychological level of social adaptation to the conditions of society, the feeling of being needed, and the desire to live. Key words: mental health rehabilitation center, social work, coordinated intervention, persons suffering from mental disorders, socio-psychological therapy.
Постановка проблеми. Вітчизняна психіатрія базується на європейській і передбачає забезпечення вільного доступу до психіатричної допомоги, реалізацію права кожного на інтеграцію в суспільство й можливість повноцінного життя особам, які страждають на психічні розлади. Реформування системи охорони здоров'я України має на меті відхід від виключно медикаментозного лікування та зосереджує увагу на можливості повернення пацієнта до максимально комфортного життя. У зв'язку із цим заслуговує на увагу ізраїльський досвід реабілітаційної роботи з пацієнтами, які страждають на психічні розлади.

Згідно з визначенням Всесвітньої організації охорони здоров'я психосоціальна реабілітація - це процес, який дає можливість людям зі слабким здоров'ям або особам, що отримали інвалідність у результаті психічних розладів досягти свого оптимального рівня незалежного функціонування в суспільстві [7].

Розвиток соціальної психіатрії в нашій країні перебуває на початковому етапі, потрібні 
дослідження, які допомогли б знайти найефективніші методи роботи й могли проводитися серед всіх суб'єктів процесу взаємодії під час надання психіатричної допомоги [3]. Психічна хвороба спричиняє часткову або повну втрату пристосованості хворого до умов навколишнього середовища. Реабілітації осіб, які страждають на психічні розлади, має ряд позитивних моментів не лише з морального боку (гуманного ставлення до них), але й $з$ економічного (після проходження курсу соціальної реабілітації $€$ ймовірність, що клієнт хоча б частково інтегрується в суспільство й стане його повноцінним членом) [2]. Одним із дієвих методів реабілітації у світі визнаний метод координованої інтервенції. Тому аналіз ефективності презентованого методу в умовах реабілітаційного центру, його експертна оцінка буде корисною та актуальною.

Аналіз останніх досліджень і публікацій. Окремим аспектам соціальної реабілітації як процесу цілеспрямованої діяльності з індивідом із відновлення втрачених або придбаних у ході соціалізації навичок і умінь присвячені праці зарубіжних науковців P. Deegan [9], S. Newman, L. Steed, K. Mulligan [10], M. Rosenberg [11], Н. Деметьєвої [3]. Серед вітчизняних науковців привертають увагу праці В. Абрамова (особливості організації медико-соціальної реабілітації психічнохворих) [1], О. Чубко, Л. Романченко (роль психосоціальної реабілітації) [7], Г. Пріб (психологічна реабілітація як складова частина комплексної реабілітації) [5], Е. Крайніков, Є. Прокопович (особливості реабілітації осіб, хворих на психічні розлади) [6]. Проте, не зважаючи на наявність наукових доробок відповідного спрямування, актуальним залишається питання розкриття успішних практик реабілітації осіб, які страждають на психічні розлади, на основі аналізу досвіду Ізраїлю.

Постановка завдання - проаналізувати ефективність застосування методу координованої інтервенції для підвищення адаптаційних можливостей осіб, які страждають на психічні розлади.

Виклад основного матеріалу дослідження. Сучасне розуміння реабілітації містить комплекс соціально-економічних, медичних, психологічних, педагогічних, юридичних, професійних та інших заходів, метою яких є якнайшвидше й найповніше відновлення втрачених людиною тих чи інших функцій, особистого й соціального статусу [1, с. 97]. Психічні розлади відрізняються великою варіабельністю як за клінічними особливостями, тими чи іншими проявами психічної дезорганізації, так і за ступенем її враженості. До найсерйозніших захворювань, що викликають виражені порушення життєдіяльності, належать шизофренія, розумова відсталість, ста- рече слабоумство, розлади настрою особистості й деякі інші [3, с. 110]. Особливу увагу в психологічної реабілітації заслуговують роботи, спрямовані на компенсацію втрачених професійних і соціально-адаптивних якостей. Головна мета реабілітації осіб, які страждають на психічні розлади, - покращення якості життя пацієнтів і допомога їм у розкритті життєвого потенціалу, мінімізація негативного впливу стигматизації та можливої дискримінації осіб із розладами психіки.

Основними заходами реабілітації осіб, що страждають на психічні розлади, є:

1. Надання кваліфікованої консультаційної, діагностичної, психокорекційної, психотерапевтичної, профілактичної допомоги хворим, які страждають на психічну патологію, та їх родинам.

2. Ведення медичної документації та обліково-звітних форм.

3. Надання медичної психотерапевтичної, реабілітаційної допомоги хворим.

4. Участь у клінічних конференціях, семінарах, тренінгах.

5. Впровадження в практику методів із профілактики кризових станів (формування навичок самостійно дбати про своє психічне здоров'я та навичок саморегуляції, опанування психотравмувальними переживаннями).

6. Впровадження в практику комплексу методів із: виховання безпечної поведінки; популяризації здорового способу життя (профілактика негативних явищ і шкідливих звичок); психогігієни (формування навичок із відновлення психічного здоров'я).

7. Психотерапевтична й психокорекційна робота з пацієнтами та їх сім'ями.

10. Просвітницька й виховна робота з пацієнтами й членами їх сімей [7].

У процесі роботи з особами, які страждають на психічні розлади, інтегруються методи когнітивно-поведінкової терапії, гештальттерапії, символдрами (робота з образами, символами, сновидіннями, спрямованою уявою), раціональної терапії, арттерапії (музична терапія, психомалюнок, різні види ручної творчої праці тощо) [7], позитивної психотерапії, сімейної терапії (для корекції сформованих внутрішніх сімейних зв'язків і відпрацювання нових стереотипів у сімейній поведінці), трансакційного аналізу, психодрами, ароматерапії, казкотерапії, релаксаційних технік, аутогенного тренування, а також виховні й просвітницькі бесіди з метою поліпшення соціальної адаптації.

Міністерство охорони здоров'я Ізраїлю визначило, що людина сама повинна визначати свої бажання та цілі, вести повноцінне й значуще життя. Мета психіатричної реабілітації в суспільстві передбачає покращення стану пацієнтів та їх оптимальну інтеграцію в суспільство. Законом «Про реабілітацію 
душевнохворих у суспільстві» (2000 рік) визначено право на «реабілітаційний кошик» (комплекс реабілітаційних послуг у громаді, які надаються різними компаніями й асоціаціями під керівництвом Міністерства охорони здоров'я), яке мають дорослі (вік старше 18 років), в яких діагностовано психічне захворювання.

Реабілітаційний кошик містить:

- послуги з реабілітації за місцем проживання: це послуги, які надаються клієнтам за місцем їх проживання, а саме район, населений пункт тощо. Надають ці послуги консультанти з реабілітації (сприяють реалізації плану реабілітації), соціальні працівники (допомагають справитись із труднощами, мотивують).

- реабілітацію у сфері зайнятості - клуб працевлаштування: для мешканців, які потребують постійного супроводу й інструктажу під час роботи. Передбачає: відпрацювання основних вмінь і навичок працівників (вчасний прихід, можливість навчатися, спілкуватися з колегами тощо); підбір посади відповідно до здібностей і побажань; постійне наставництво; послуги в організації дозвілля; фінансування стоматологічного лікування; фінансову допомогу для придбання початкового необхідного обладнання для самостійного життя тощо [11].

Реалізація права на реабілітаційний кошик $€$ важливим кроком у роботі з душевнохворими. На всій території Ізраїлю існують відповідні служби підтримки душевнохворих та їх сімей, які надають інформацію та рекомендації сім'ям із питань кошика реабілітації, законів, прав інвалідів тощо.

Основною метою та завданням реабілітації осіб, які страждають на психічні розлади, є не повернення здоров'я, а пошук і розкриття функціональних можливостей індивіда для полегшення його життя та повноцінного існування в суспільстві, а тому весь комплекс заходів реа- білітації спрямований на відновлення та розвиток активного соціального суб'єкта, особистості, здатної до вольових зусиль, трудової мотивації, саморозвитку [2]. Практичний досвід переконує, що в такому процесі важливу роль відіграє методика координованої інтервенції.

Методика координованої інтервенції (далі-IMR) - це програма, розроблена в період із 2000 по 2002 рік як частина проєкту, заснованого на доказовій практиці (далі - ЕВР), для надання допомоги особам, які страждають на психічні розлади, з метою отримання інформації про хворобу й навички, які вони потребують, щоб мінімізувати наслідки хвороби, встановити важливі особисті цілі й просунутися до них у своєму повсякденному житті [8, с. 11].

3 метою виявлення ефективності впровадження методу координованої інтервенції як умови успішної реабілітації осіб, які страждають на психічні розлади, нами було проведено експериментальне дослідження. Дослідження проводилося протягом 2019-2020 років у реабілітаційному центрі психічного здоров'я міста Арада, Ізраїль. Констатувальний експеримент був проведений із метою діагностики стану проблем і поширених симптомів осіб, які страждають на психічні розлади, за допомогою анкетування, спостереження та інтерв'ю. Опитування проводилось у письмовій формі й анонімно. Усього було опитано 50 осіб, з яких 10 співробітників і 40 осіб, які страждають на психічні розлади, що у відсотковому співвідношенні відповідно становить 20\% і 80\%.

Аналіз отриманих даних свідчить, що із 40 хворих, які беруть участь в експерименті, в 7 (17,5\%) спостерігаються проблеми з мисленням, у 9 (22,5\%) - проблеми настрою, в $17(42,5 \%)$ є негативні симптоми, в 5 (12,5\%) психотичні симптоми й у 2 (5\%) - споживання алкоголю та наркотиків.

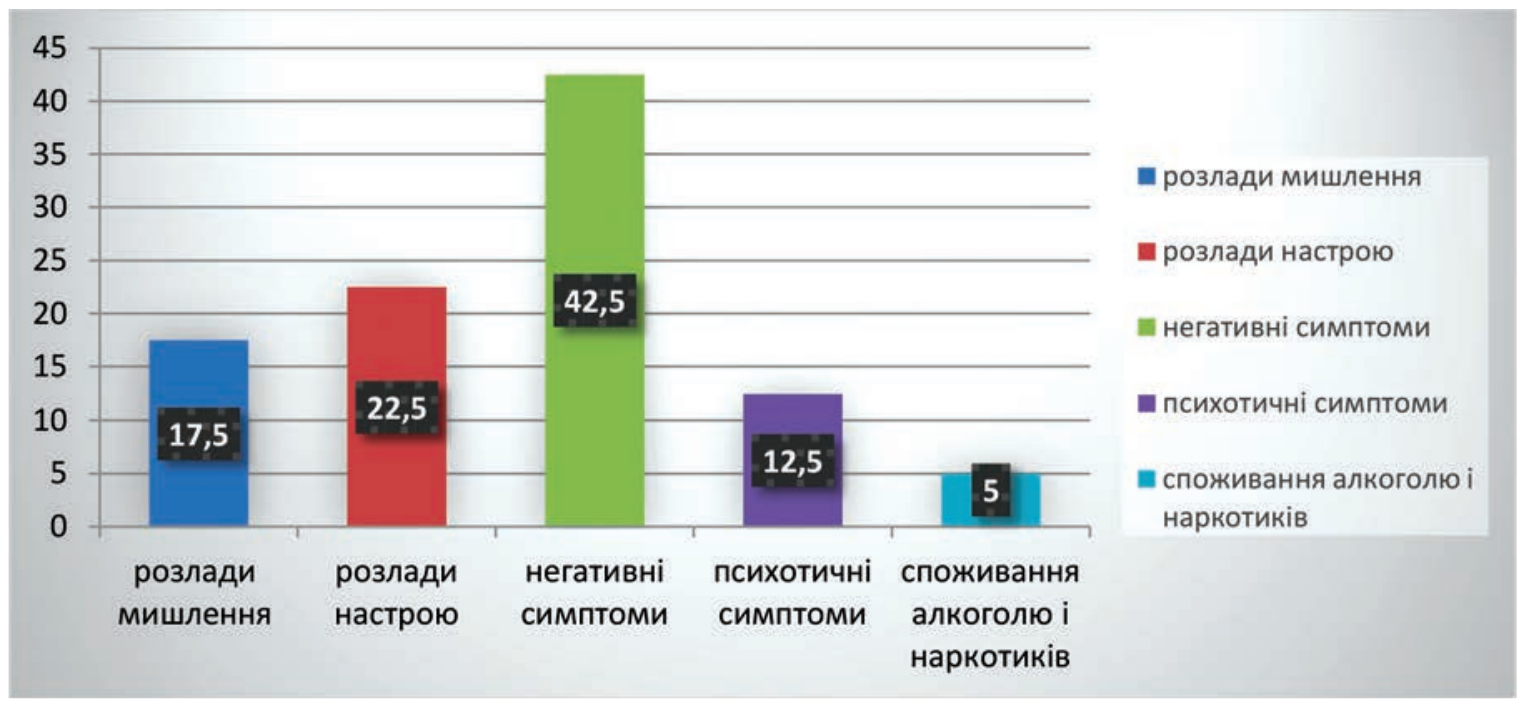

Рис. 1. Зведені результати констатувального етапу експерименту 
На підставі результатів відповідей пацієнтів і співробітників ми визначили, що найпоширенішою проблемою $є$ прояв негативних симптомів, таких як відсутність інтересу, незадоволеність, відсутність прояву почуття та небажання спілкуватися з людьми. Важливо відзначити, що така проблема серйозно ускладнює життя хворого, й це може свідчити про наближення рецидивів захворювання.

Отже, стан психологічної реабілітації осіб, які страждають на психічні розлади, знаходився на недостатньому рівні. Саме тому перед нами постало завдання, пов'язане з вдосконаленням стратегій, які допоможуть справитися з найбільш розповсюдженими проблемами й симптомами осіб, які страждають на психічні розлади.

У контексті пропонованого дослідження очевидно, що неможливо остаточно розмежувати сфери впровадження методики координованої інтервенції, тому що процес реабілітації осіб, які страждають на психічні розлади, має цілісний, системний характер, здійснюється в єдиному реабілітаційному просторі й визначений нормативами навчального часу. Щоб одужати або успішно жити з будь-якою хронічною хворобою, необхідно, щоб люди навчилися справлятися зі своїми хворобами в співпраці із соціальними працівниками, лікарями й інструкторами лікування. Практика підтверджує необхідність навчання самоконтролю хвороби для покращення хронічних захворювань [10].

Метод координованої інтервенції навчає стратегій самоконтролю хвороб для пацієнтів із важкими психічними захворюваннями й містить: інформацію про психічне захворювання та його лікування, когнітивно-поведінкові підходи до дотримання режиму прийому ліків (наприклад, включення підказок для прийому ліків у щоденній рутині), розробку плану профілактики рецидивів, посилення соціальної підтримки за допомогою навчання соціальних навичок.

Подальше експериментальне дослідження було пов'язане із застосуванням такої методики з метою допомоги особам, які страждають на психічні розлади, отримати прогрес в одужанні, включаючи об'єктивні цілі (соціальні відносини, робота) й суб'єктивні (цілеспрямованість, надія, впевненість). У процесі формувального експерименту була здійснена спроба організації координованої інтервенції осіб, які страждають на психічні розлади, в соціумі.

В експерименті взяли участь клієнти, які отримують послуги в реабілітаційному центрі. Учасники експериментального дослідження мали такі характеристики: 18-65 років; бажання вчитися; діагноз, що позначає важке психічне захворювання (психічний розлад, шизофренія, депресія, шизофренічний роз- лад, біполярний розлад і порушення соціальної, професійної діяльності або функції самообслуговування).

Інструктори використовують різні методи для оптимізації навчання. Зустрічі проходили щотижня протягом 7 місяців і складалися з 9 модулів, які викладалися послідовно. Кожен IMR-модуль містить навчальний матеріал, який викладає основні пункти теми й робочі листи для навчання. Кожен модуль тривав приблизно 2 тижні, але змінювався залежно від можливостей і переваг пацієнтів:

1. Модуль «Стратегії відновлення» мав на меті підвищити поінформованість про відновлення, встановлення особистих цілей відновлення, розробку планів для досягнення цілей.

2. Модуль «Практичні факти про шизофренію» передбачав розвіяння міфів про шизофренію, огляд джерел стигми й інформацію про людей із шизофренією, які ведуть продуктивне життя.

3. Модуль «Модель стрес-уразливості й стратегії спілкування» мав на меті обговорення стратегії зменшення стресу й біологічної вразливості, а також інформування учасників групи про варіанти лікування.

4. Модуль «Побудова соціальної підтримки» передбачав навчання стратегії підвищення підтримки (пошук місць для знайомства з людьми, навички спілкування, наближення до людей).

5. Модуль «Ефективне використання ліків» за мету мав збільшення навичок для обговорення медичних питань із лікарем, допомогу учасникам групи оцінити переваги й недоліки прийому ліків, навчання поведінкової терапії для полегшення отримання ліків.

6. Модуль «Зменшення рецидивів» допомагав учасникам розробити індивідуальний план профілактики рецидивів.

7. Модуль «Боротьба зі стресом» спрямований на визначення та реалізацію стратегій запобігання стресу.

8. Модуль «Боротьба з проблемами й стійкими симптомами» допомагав учасникам у виявленні загальних проблем і симптомів, які викликають рецидиви хвороби, й практиці стратегій подолання стійких симптомів.

9. Модуль «Потреби в системі психічного здоров'я» спрямований на визначення страхових пільг, на які мають право пацієнти, й допомогу учасникам у визначенні стратегій для захисту себе в системі психічного здоров'я.

Учасники експерименту брали участь в індивідуальних і групових сесіях IMR, які складаються в стандартизовану структуру:

1. Неформальне спілкування (клініцист і клієнти використовували цей час для побудови взаємовідносин та обговорення будьяких додаткових питань, які необхідно було розглянути в кінці сесії). 
2. Перегляд змісту попередніх сесій (із метою оцінки розуміння та збереження інформації та навичок клієнтів).

3. Перегляд домашнього завдання з попередньої сесії (розгляд завершення домашніх завдань, оцінка успішних зусиль клієнтів, труднощів, з якими стикалися).

4. Дотримування цілей (оцінка прогресу клієнтів у досягненні особистих цілей, виявлення перешкод, планування нових цілей).

5. Встановлення програми поточного сеансу (спільне встановлення плану зустрічі).

6. Навчання нового матеріалу й відпрацювання нових стратегій (розглянути й вивчити роздаткові матеріали з використанням комбінації освітніх, мотиваційних і когнітивно-поведінкових стратегій, адаптованих до знань і вмінь кожного пацієнта).

7. Спільне формулювання домашнього завдання на наступний тиждень (домашне завдання розроблялось за матеріалами поточної сесії з метою досягнення особистих цілей клієнтів, подолання будь-яких перешкод).

8. Узагальнення прогресу, який досягнутий у поточній сесії (на основі інформації від клієнтів).

З 40 осіб, які були включені в програму лікування IMR, 39 завершили лікування та один покинув групу після першого місяця. Тривалість лікування склала 8 місяців. Якщо розглядати демографічні й клінічні характеристики групи, слід зазначити, що в більшості учасників був діагностований діагноз шизофренія (25\%) або шизофренічний розлад (35\%).

Групою фахівців керував соціальний працівник, а сеанси тривали близько години: кожна сесія складалася з двох 45-хвилинних зустрічей із 15- хвилинною перервою між ними На додаток до клієнтів в групі, які мали домашні завдання, були також розроблені аналогічні завдання для керівників груп із метою покращення згуртованості групи й забезпечення зразків для наслідування. Матеріал IMR був розглянутий із використанням PowerPoint у половині сесій залежно від наявності проєктора з рідкокристалічним дисплеєм, що надало групі відчуття класної кімнати. На інших сесіях матеріал був розглянутий у паперовому варіанті. Візуальний вплив модулів у поєднанні з фотографіями був корисним для клієнтів, які краще відповідали візуальному, а не слуховому навчанню. Використання PowerPoint i PK-проєктора в груповому контексті не тільки забезпечив сприятливе середовище для виконання програми, але й надав можливість учасникам групи моделювати завершення робочих аркушів, а електронне зображення проєктувалося на дошці. Клієнтам подобались ці зміни, що сприяли формуванню відчуття класу, а не групи. Регулярні сесії забезпечували вірну прихильність до групової структури й основних стратегій IMR.
За результатами формувального експерименту можемо констатувати покращення показників щодо симптомів у порівнянні з констатувальним експериментом. Так, розладами мислення страждало спочатку 7 осіб, а після проведення заходів - 5 осіб. Розлади настрою спостерігалися в 9 осіб, а після проведення координованої інтервенції - лише в 5 осіб. Негативні симптоми були зафіксовані в 17 осіб, а після втручання - в 5 осіб.

ПіслявикористанняIMRпацієнтипродемонстрували позитивну динаміку в області лікування захворювань і відновлення (Таблиця 1). Учасники повідомили про: значне зниження вираження симптомів від вихідного рівня; покращення ефективності стратегії подолання симптомів хвороби, що вимірюються за шкалою навичок подолання від базової інформації; збільшення самоконтролю над хворобою, про що свідчить збільшення балів за шкалою IMR від вихідного до посттестового; покращення знання про психічні захворювання після лікування та спостереження за хворобою.

Таблиця 1

Зведені результати формувального експерименту

\begin{tabular}{|c|c|c|}
\hline $\begin{array}{c}\text { Перелік } \\
\text { симптомів }\end{array}$ & $\begin{array}{c}\text { Конста- } \\
\text { тувальний } \\
\text { експеримент }\end{array}$ & $\begin{array}{c}\text { Форму- } \\
\text { вальний } \\
\text { експеримент }\end{array}$ \\
\hline $\begin{array}{c}\text { Управління } \\
\text { хворобою }\end{array}$ & 0 & 20 \\
\hline $\begin{array}{c}\text { Ефективне } \\
\text { розв'язання } \\
\text { проблем }\end{array}$ & 5 & 15 \\
\hline $\begin{array}{c}\text { Знання } \\
\text { хвороби }\end{array}$ & 1 & 39 \\
\hline $\begin{array}{c}\text { Соціальна } \\
\text { підтримка }\end{array}$ & 20 & 39 \\
\hline $\begin{array}{c}\text { Розлади } \\
\text { мислення }\end{array}$ & 7 & 5 \\
\hline $\begin{array}{c}\text { Розлади } \\
\text { настрою }\end{array}$ & 9 & 5 \\
\hline $\begin{array}{c}\text { Негативні } \\
\text { симптоми }\end{array}$ & 17 & 2 \\
\hline $\begin{array}{c}\text { Психотичні } \\
\text { симптоми }\end{array}$ & 5 & \\
\hline $\begin{array}{c}\text { Споживання } \\
\text { наркотиків } \\
\text { і алкоголю }\end{array}$ & 2 & \\
\hline
\end{tabular}

Таким чином, отримані дані підтверджують доцільність реалізації методики координованої інтервенції для осіб, які страждають на психічні розлади, отримують послуги в типових умовах психіатричного реабілітаційного центру й припускають, що участь у програмі пов'язана з перевагами в лікуванні захворювань, прогресом в одужанні й поліпшенням функціонування. Ці дані свідчать про те, що 
контрольовані дослідження є наступним кроком до оцінки впливу програми IMR.

Висновки 3 проведеного дослідження. у ході дослідження надано характеристику роботи реабілітаційного центру психічного здоров'я міста Арада, Ізраїль, описано впровадження методики координованої інтервенції з особами, які мають психічні розлади, в основі якої - навчання пацієнтів основ самоконтролю хвороби, заснованим на моделі стрес-уразливості, тобто впливі ліків, посиленні соціальної підтримки й залученні до трудової діяльності тощо. За результатами роботи спостерігаємо значне покращення стану здоров'я пацієнтів. Доведено, що метод координованої інтервенції здатен підвищити рівень соціальної адаптованості осіб, які страждають на психічні розлади, до умов соціуму й домогтися прогресу в їх одужанні.

\section{ЛІТЕРАТУРА:}

1. Абрамов В.А. Медико-социальная реабилитация больных с психическими расстройствами : Руководство для врачей-психиатров, психологов и социальных работников. Донецк : Каштан, 2006. 268 с.

2. Богданова О.А. Організація соціальної роботи в психоневрологічних інтернатах. Вологда, 2006. $58 \mathrm{C}$.

3. Дементьева Н.Ф., Шаталова Е.Ю., Соболь А.Я. Организационно-методические аспекты деятельности социального работника. Москва, 2002, 305 с.
4. Комарова Н.В. Координована інтервенція як метод підвищення адаптаційних можливостей душевнохворих на прикладі реабілітаційного центру Ізраїлю : автореф. магістр. роботи :231. Миколаїв, 2019. 13 c.

5. Пріб Г.А. Психологічна реабілітація як складова комплексної медико-соціальної реабілітації психічнохворих. Етіологія, патогенез, клініка та лікування психічних розладів. URL: https://uvnpn.com. ua/upload/iblock/535/535453bf0ca73d611a8714fa3f60 a3d5.PDF.

6. Ревука Т.О., Крайніков Е.Г., Прокопович Є.М. Особливості ресоціалізації та реабілітації осіб, хворих на психічні розлади. Психологія. Педагогіка. Соціальна робота. 2013. № 1 (7). С. 51-54.

7. Чубко О.Б., Романченко Л.В. Роль та місце психосоціальної реабілітації в системі психіатричної допомоги. Нейро News. 2012. № 3 (38). URL: https:// neuronews.com.ua/ua/archive/2012/3\%2838\%29/ article-636/rol-ta-misce-psihosocialnoyi-reabilitaciyi-vsistemi-psihiatrichnoyi-dopomogi\#gsc.tab=0.

8. Anthony W.A. Recovery from mental illness: the guiding vision of the mental health service system in the 1990s. Psychosoc Rehabil Journal. 1993. No. 16. P. 11-23.

9. Deegan P. Recovering our sense of value after being labeled mentally ill. Journal of Psychosocial Nursing. 1993. No. 31 (4). P. 7-11.

10. Newman S, Steed L, Mulligan K. Selfmanagement interventions for chronic illness. Lancet, 2004. $364 \mathrm{p}$.

11. Rosenberg M. Conceiving the Self. New-York : Basic Books, 1979. 319 p. 